\title{
Encephalitis in Nepal: The Visitation of The Goddess of The Forest
}

\author{
Maj A Henderson \\ BMedSci, MRCP, RAMC \\ British Military Hospital, Dharan
}

\begin{abstract}
SUMMARY: Examination of hospital records from BMH Dharan and the large Nepalese hospital at Biratnagar has revealed a worrying trend in the incidence of acute encephalitis in the area of the British Military Cantonment at Dharan. The weight of available evidence strongly favours Japanese Encephalitis Virus (JEV) as the aetiological agent. Serological studies from healthy Nepalese from the Dharan area and animals from the Cantonment farm indicate that intense transmission of JEV occurs within the Cantonment area. Japanese Encephalitis (JE) must now be regarded as a serious threat to British Military personnel and dependants living in or visiting Nepal. Protective measures, particularly active immunisation are discussed.
\end{abstract}

\section{Introduction}

The British Military Cantonment at Dharan lies on the nonthern fringe of the Terai region of eastern Nepal in the Koshi Zone. The Terai is a flat fertile rice growing plain bordering the northern states of India. The Cantonment supports a population of British and Gurkha soldiers and their families and a large force of local Nepalese who live or work within its area.

Although acute encephalitis, known to the locals as the "visitation of the goddess of the forest," has probably always been a feature of life on the Terai, it appeared to be uncommon in the Dharan area before 1970. Since then each summer, cases have been admitted to the BMH and to the local Nepalese hospitals in increasing numbers. This in conjunction with the appearance of severe epidemics of Japanese Encephalitis (JE) in neighbouring parts of the Indian subcontinent ${ }^{1}, 2,3$ suggested a threat might exist to British Military personnel living in or visiting Nepal. This paper explores the extent of the encephalitis threat, presents evidence implicating the Japanese Encephalitis Virus (JEV) as the principal casual agent and suggests measures that might be taken to reduce the risk of JEV transmission to man and the consequences of this.

\section{Materials and Methods}

The study was carried out in 4 phases.

PHASE I: The clinical records of all patients admitted to BMH Dharan with acute encephalitis were examined. The case finding was probably incomplete due to the absence of a data retrieval system. Clinical and laboratory data were extracted

\footnotetext{
*Winches Farm is a field station near St Albans of the London Schoot of Hygiene \& Tropical Medicine.
}

from the records and where available the results of flavivirus serology wert examined. Serum was tested $\frac{\dot{N}}{N}$ for evidence of flavivirus antibodies either at the 0 Special Pathogens laboratory, Porton or the Virus ${ }_{\omega}$ Reference laboratory, Colindale.

PHASE II: Dharan lies on the norihern fringe of the Terai in the Koshi Zone. To determine tre oxtent of the encephalitis problem in the souther Terai the inpatient analysis data from Biratnagar hospital was examined. Biratnagar is the largest town $\vec{\varphi}$ in the Koshi Zone and lies almost due south of Dharan near the Indian border. It is importai from the military view-point in that all milita personnel and families flying to and from Katmandu do so via Biratnagar airport.

PHASE III: To detect evidence of Japanzeco Encephalitis Virus (JEV) transmission on the Dharan Military Cantonment blood was taken from known amplifying hosts on the Cantonment resettlement farm. Serum from 16 pigs of varying ages was 3 tested by Haemagglutination Inhibition (HAI) for JEV antibody at the Arbovirus Unit, Winches Farm ${ }^{*}$ London and serum from adult buffaloes, chickens $\vec{\nabla}$ and ducks tested by HAI at the Armed Forces $\frac{\varrho}{\vec{F}}$ Research Institute of Medical Sciences (AFRIMS) $\stackrel{\text { ? }}{\circ}$ Bangkok. All the animals tested had spent their 3 . cntire lives on the farm.

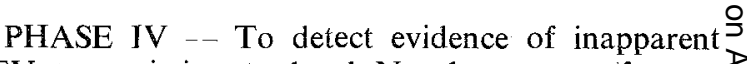
JEV transmission to local Nepalese serum from ao sample of 20 Nepalese men working on the Cantonment was tested by HAI at AFRIMS. Serum fromer 20 UK soldiers and families was similarly tested to N gauge their susceptibility to JEV. \section{年}




\section{Results}

PHASE I - Clinical data

The notes of 43 patients were reviewed, of whom eight were seen personally in 1982 .

Age and Sex. The mean age of the group was 15 years (range 5 months to 63 years). 27 (62\%) were under 20 years of age. The sex incidence was similar (20 males, 23 females).

Place of Domicile. Dharan - 24, Terai - 14, Hills - 3, Military Cantonment - 2 .

Season. Although occasional cases occurred throughout the year the majority occurred in relation to the summer monsoon (Fig. 1). $74 \%$ of cases occurred between the months of August and October.

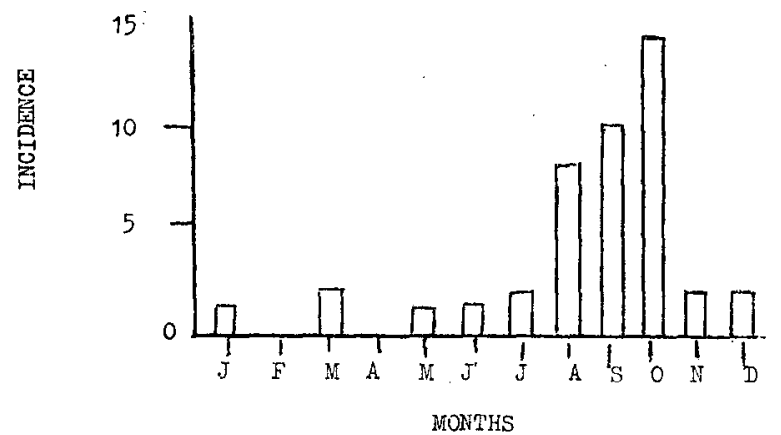

Fig. 1 Monthly incidence of encephalitis

Yearly Incidence. The disease appears to have been uncommon before 1970. Since then the annual incidence has been increasing (Fig. 2).

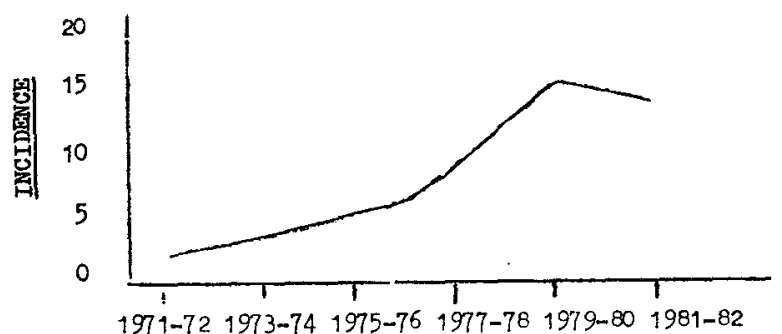

YEARS

Fig. 2 Annual incidence of encephalitis

Mode of onset. The majority had a non-specific prodrome lasting a few days before the onset of definite encephalitic features. In addition to malaise, anorexia and fever, $58 \%$ had severe headache and $32 \%$ vomiting. In $19 \%$ the prodromal symptoms were not well recorded. Towards the end of this stage and often precipitating hospital admission came symptoms of severe cerebral dysfunction. 3 Disturbance of consciousness occurred in $100 \%, \propto$ aphonia in $42 \%$ and grand mal fits in $40 \%$. In a minority the disease was explosive with high fever and a rapidly fatal acute brain syndrome.

One patient demonstrated wildly disturbed be- $\overrightarrow{\vec{F}}$ haviour for 3 days before lapsing into fatal coma. Physical Findings

(a) Fever. $76 \%$ were febrile on admission, often $\frac{\bar{\omega}}{\omega}$ to an alarming degree. Their mean oral or rectal $\stackrel{\Phi}{\complement}$ temperature was $39^{\circ} \mathrm{C}$ (range $37.8-40.6$ ). The fever@ had a swinging character and lasted on average $7 \vec{\circ}$ days (range 1-24 days).

(b) Tachycardia: Sinus Tachycardia was the rule $\vec{\omega}$ with a mean heart rate of 113 beats/minute. In? only one patient was an inappropriate bradycardia noted (rate $50 \mathrm{~B} / \mathrm{M}$ ).

(c) Neurological Findings: See Table I.

No other abnormal signs were noted.

Table I

Neurological findings on Admission

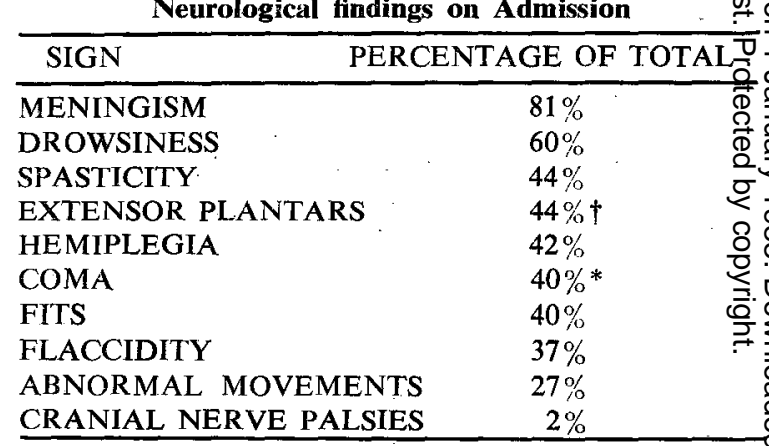

Excludes children of less than 1 year

*Implies unresponsive to pain

Outcome. Eighteen $(42 \%)$ died in hospital, mostlyo within a few days of admission. Age and sex did not relate to prognosis but the presence of coma on admission accurately predicted a fatal outcome Of those in coma $88 \%$ died, while in drowsy patients the death rate was only $11 \%$. Of the 25 who sur vived to leave hospital only $28 \%$ made a good recovery. The remainder had varying degrees of neurological dysfunction which was judged as severo in $52 \%$. Long term follow-up was not possible.

Management. Supportive and nursing care formed the cornerstone of management. Some patients re음 ceived corticosteroids or antimicrobials but no con $\rightarrow$ sistent policy was employed.

(a) Laboratory Investigations: As the study was largely retrospective the laboratory data in placesu was incomplete. 
(b) Chest Radiology: Most patients had an early chest X-ray. None was abnormal.

(c) Biochemistry: Liver function tests were normal. The mean serum sodium was $131 \mathrm{mmol} / 1$ (range 118-142), mean potassium $3.8 \mathrm{mmol} / \mathrm{l}$ (range 1.9-5.6) and mean urea $6.8 \mathrm{mmol} / 1$ (range 2.3-17.6). In those with an elevated blood urea the abnormality was corrected by rehydration.

\section{Haematology (Table II)}

(a) Malarial Parasites: Thick and thin blood films from 15 patients were examined for malarial parasites with negative results.

(b) Electrocardiogram: ECG was recorded in 9 cases. Apart from sinus tachycardia no abnormalities were noted.

(c) Cerebrospinal fluid: CSF was examined in 35 patients. Ziehl-Neelsen and Gram stains were negative. In $34 \%$ the initial CSF was normal but in $45 \%$ there was a modest lymphocytosis and in $37 \%$ an elevated protein. In the 14 patients where a simultaneous blood and CSF sugar was measured the mean blood - CSF difference was $1.6 \mathrm{mmol} / 1$ (range 0.7-2.6). In four cases a traumatic puncture obscured the results.

(d) Arbovirus Serology: Serum from a few patients was tested for antibodies to Dengue I, Tembusu, West Nile, Kunjin and Chikungunya viruses with negative results. In 25 cases serum was tested for antibody to Japanese Encephalitis Virus (JEV). In six only acute specimens were tested due

Table 11

Haematological Parameters on Admission

\begin{tabular}{lccc}
\hline Parameter & $\begin{array}{c}\text { Number } \\
\text { Tested }\end{array}$ & Mean & Range \\
\hline Haemoglobin gm/dl & 36 & 12.2 & $4.0-17.1$ \\
WBC X 10 $/ 1$ & 37 & 14.6 & $5.4-45$ \\
Percentage neutrophils & 30 & 78 & $49-95$ \\
ESR & 19 & 29 & $8-56$ \\
\hline
\end{tabular}

Table III

Japanese Encephalitis Antibody Titre

\begin{tabular}{lccl}
\hline 1 & 1978 & Negative & $1: 160^{*}$ \\
2 & 1978 & Negative & $1: 80$ \\
3 & 1982 & $<1: 10$ & $1: 20$ \\
4 & 1982 & $1: 40$ & $1: 80$ \\
5 & 1982 & $1: 20$ & $1: 80$ \\
6 & 1982 & $1: 10$ & $1: 40$ \\
7 & 1982 & $1: 10$ & $1: 40$ \\
8 & 1982 & $1: 10$ & $1: 160$ \\
\hline
\end{tabular}

* Specific JEV IgM to early death, all were negative. Of the 19 paired sets 11 were reported as negative. Eight cases showed rising antibody titres against JEV, six of which were personal cases from the 1982 outbreak. The results are shown in Table III.

PHASE II --. Inpatient analysis data from Biratnagar Hospital

Accurate data was available for patients admitted with acute encephalitis since 1975. A total of 673 cases were recorded. The sex ratio showed a slight male preponderance of 1:5:1. The mortality was $34 \%$. Follow-up data of survivors was not available. The overall trend revealed an increasing annual incidence since 1975 (Fig. 3).

The monthly incidence showed occasional cases occurred throughout the year with a vory large increase in admissions in the early phase of the summer monsoon (Fig. 4).

The age specific attack rate showed a marked preponderance of school-aged children (Fig. 5).

Examination of the records of the small Nepali hospital in Dharan showed a pattern of incidences very similar to that of BMH.

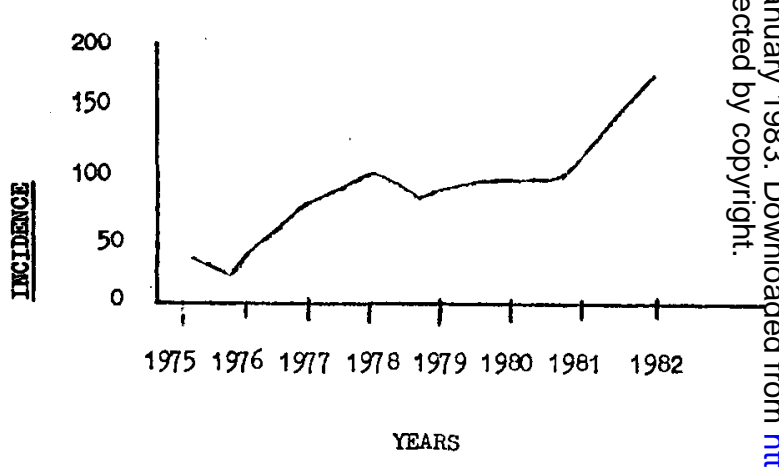

Fig. 3 Annual incidence of cases of acute encephalitis admitted to Biratnagar Hospital

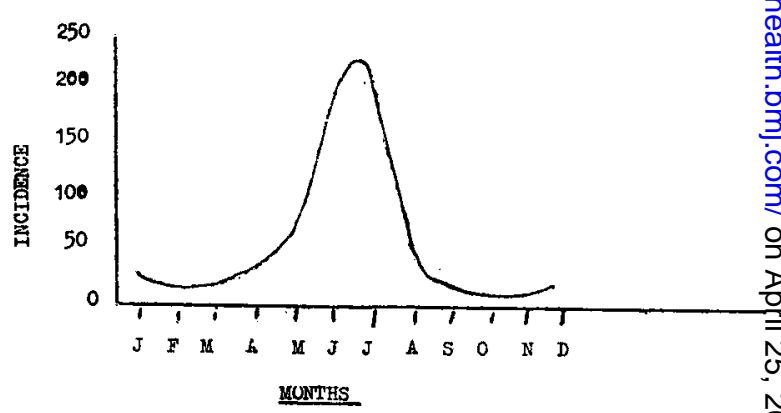

Fig. 4 Monthly incidence of acute encephalitis 


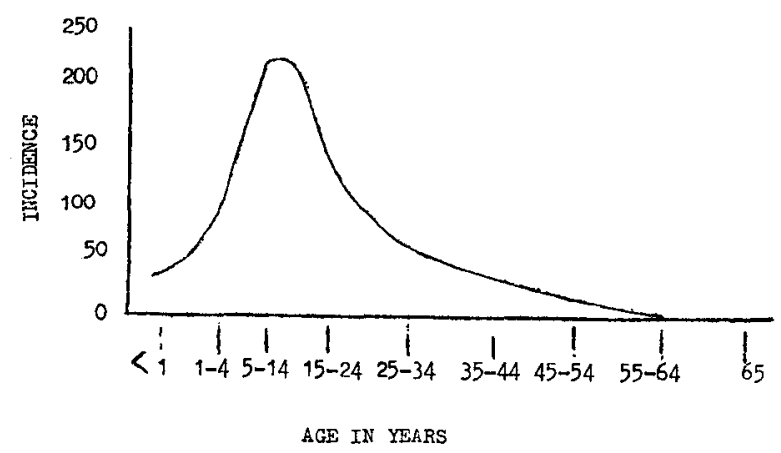

Fig. 5 Age specific incidence of acute encephalitis

\section{PHASE III. Animal Serology}

Serum from a variety of animals from the Dharan Cantonment farm was examined by Haemagglutination Inhibition (HAI) for antibody to JEV and West Nile Virus (WNV). The latter acted as a nonspecific marker of flavivirus activity, to exclude the possibility of the JEV antibody merely representing a general flavivirus response rather than a specific JEV response. The results are shown in Table 4.

Serum from five adult buffaloes also showed JEV antibody up to a titre in 1:80. Interestingly none of the pigs or buffaloes tested was negative. Five ducks and six chickens from the large population of farm birds were tested with negative results.

Table IV

Flavivirus Serology in Cantonment pigs

\begin{tabular}{ccc}
\hline Pig & JEV Titre & WN Titre \\
\hline A1 & 640 & 40 \\
A2 & 640 & $<20$ \\
A3 & 1280 & 80 \\
A4 & 640 & 80 \\
A5 & 640 & 80 \\
B1 & 160 & 20 \\
B2 & 320 & 40 \\
B3 & 320 & 40 \\
B4 & 160 & 40 \\
B5 & 320 & $<20$ \\
C1 & 160 & 80 \\
C2 & 320 & 80 \\
C3 & 160 & 80 \\
C4 & 120 & $<20$ \\
C5 & 160 & 40 \\
C6 & 160 & $<20$ \\
\hline
\end{tabular}

JEV-Japanese Encephalitis Virus.

WN-West Nile Virus. A-Pigs four years old.

$B$-Pigs 11 months old. C-Pigs six months old.

\section{PHASE IV. Healthy Human Serology}

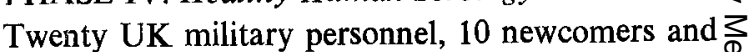
10 residents of at least 12 months standing, were $\varrho$ tested for JEV antibody by HAI. All were negative. $\bigcirc$

Twenty Nepalese adults working on the Cantonment were similarly tested. $55 \%$ showed low titres of JEV antibody (titre of 10-80) indicating previous $\overrightarrow{\vec{F}}$ (remote) inapparent infection with JEV.

\section{Discussion}

There can no longer be any doubt that a serious $\varrho$ threat from flavivirus encephalitis exists in the Terai ${ }_{\infty}$ region of southern Nepal. The Koshi Zone which $\vec{O}$ includes the area around the British Military Canton-? ment at Dharan is one of the most severely affected $\vec{\omega}$ areas $^{4}$. Sporadic encephalitis, known to the local people as the "visitation of Goddess of the forest," has probably always been a feature of life in the Terai but in the last decade the disease appears to $\frac{\vec{N}}{\mathrm{~N}}$ have taken on an epidemic form, not only inco $\mathrm{Nepal}^{3,}{ }^{*}$ but in nearby areas of India ${ }^{3}$ and West Bengal 1,2 . In addition examination of hospital records from Biratnagar on the southern fringe $\mathbb{B f}_{0}$ the Koshi Zone and from Dharan to the north has revealed an alarming annual increase in reported $\vec{C}$ cases of acute encephalitis. Small numbers of cases are reported throughout the year with a sharp if crease occurring in relation to the summer monsoofl. Interestingly the epidemics occur earlier in the southern Terai (Biratnagar) where $61 \%$ of the cas\&s are reported between May and July compared win the northern Terai (Dharan) where $74 \%$ of casêso occur between August and October.

The strongly seasonal character of the epidemicso favour an arbovirus aetiology. Early clues as to the $\frac{0}{\Phi}$ nature of the casual agent came from West Bengal and India 1, 2, 3, 4 where Japanese Encephalitis Virus $\overrightarrow{0}$ (JEV) was identified as the cause of summer ence- 3 phalitis. In $1978 \mathrm{JEV}$ was identified on serological grounds as cause of summer encephalitis in Nepal $\stackrel{\text { ? }}{-}$ with confirmation in following years ${ }^{3}, 4$. The $\overline{3}$ ecological substrate for JEV transmission is ideally met in the Terai. There are vast expanses of rices paddy so favoured by the prime vectors Culex ${ }_{\overparen{D}}$ tritaeniorrhynchus and Culex vishnui ${ }^{2,}$ 5, 6, 7 which are the dominant species ${ }^{4}$. The main amplifying hosts, pigs, buffaloes, cattle, wild and domestic birds 3 which are essential to JEV transmission abound.

The JEV cycles involves mosquito vectors and $\frac{\rho}{3}$ animals with man being involved incidentally. In most JEV endemic areas pigs seem to be main amplifying host ${ }^{8,}, 9,10,11$. Newly born pigs lose their $\frac{7}{0}$ maternal antibody by 6 months ${ }^{12}$ and become fully susceptible to JEV. In areas of high transmission all N susceptible pigs are infected within 12 months ${ }^{13}$. N Once infected the young pig develops an intense? 


\section{Sistos \\ GY APPOINIMEN \\ TO HER MAUESTY THE DUEEN
LIVERY A MILITARY TAILOFE \\ Gieves \& Hawkes \\ of Savile Row

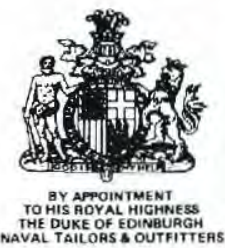 \\ Officially Appointed \\ Tailors, Hatters and Outfitters to \\ The Royal Army Medical Corps}

In our additional role as Civilian Tailors and Outfitters

we offer an extensive range of ready to wear clothing, clothing, shirts and accessories for formal and casual occasions.

We are now Stockists of the famous

'BARBOUR' FIELD COAT RANGE

No. 1 SAVILE ROW, LONDON W.1 Tel: 014342001

1, HIGH STREET, CAMBERLEY, SURREY Tel: 027663659
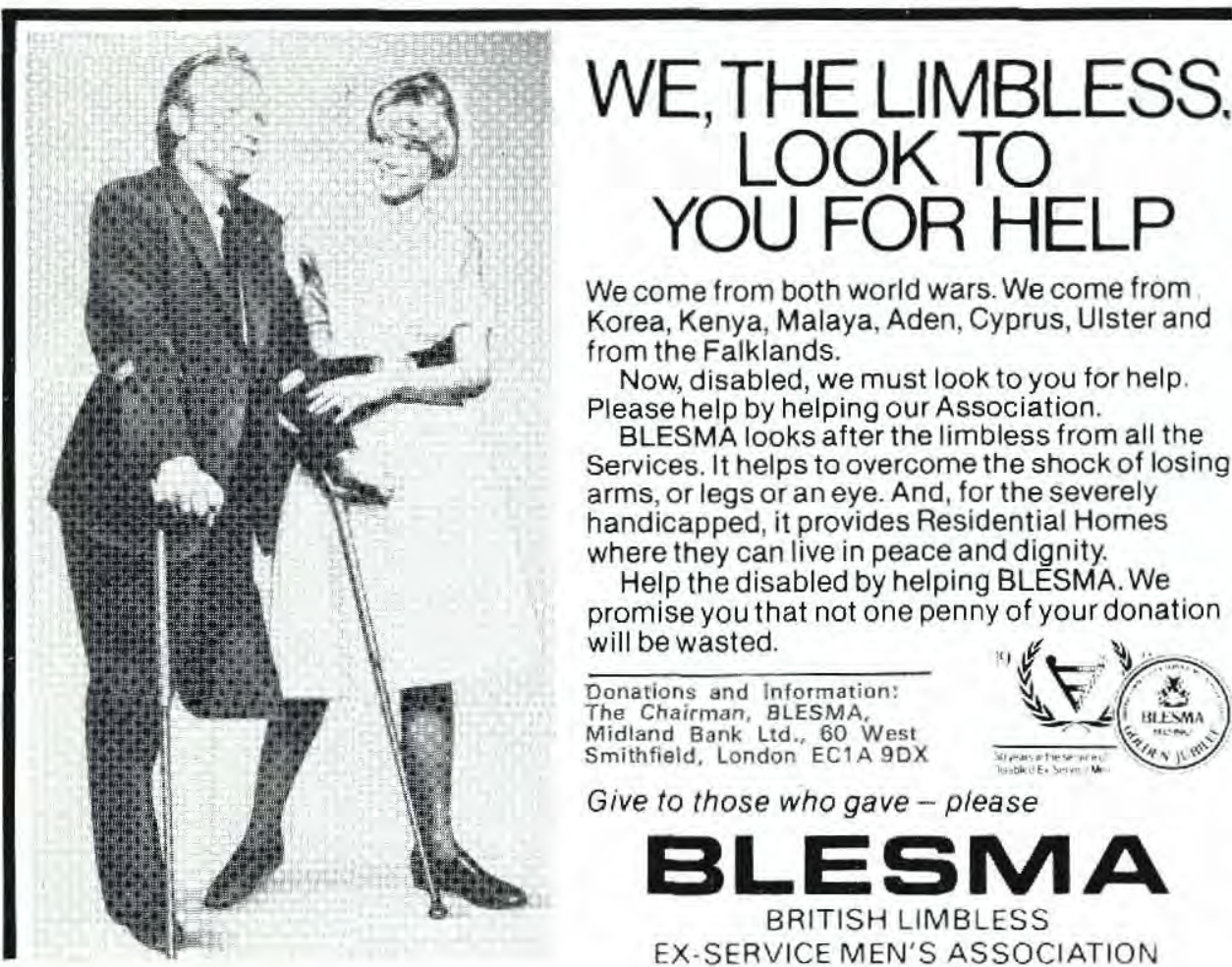

We come from both world wars. We come from Korea, Kenya, Malaya, Aden, Cyprus, Ulster and from the Falklands.

Now, disabled, we must look to you for help. Please help by helping our Association.

BLESMA looks after the limbless from all the Services. It helps to overcome the shock of losing arms, or legs or an eye. And, for the severely handicapped, it provides Residential Homes where they can live in peace and dignity.

Help the disabled by helping BLESMA. We promise you that not one penny of your donation will be wasted.

Donations and Information:
The Chairman, BLESMA
Midland Bank Ltd., 60 West
Smithfield, London EC1A 9DX

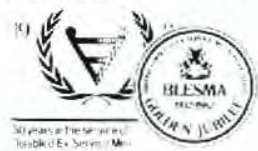

Give to those who gave - please

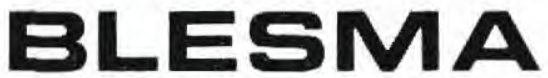

BRITISH LIMBLESS

EX-SERVICE MEN'S ASSOCIATION 
essential during the months of May to November when the risk is highest. It is however unsafe to assume visits at other times are without risk as Culex tritaeniorrhynchus is active at a low level throughout the year ${ }^{35}$ and cases of encephalitis do occur in the cool months.

3. The farm. A potential pool of JEV exists on the cantonment farm where an interface of susceptible people, mosquitoes and amplifying hosts exists. The domestic fowl probably act as amplifying hosts ${ }^{15,18}$ and could be removed at little economic cost. Certainly the keeping of fowl in the residential quarters should be discouraged. The adult pigs and buffaloes are immune to viraemia and thus not only of no risk to man but by acting as an immunological brake of JEV transmission may be protective ${ }^{14,15}$. Young pigs however greatly amplify the virus pool and represent a threat. It has been shown that pigs immunised against JEV are much less likely to produce a mosquitoinfecting viraemia when challenged with $\mathrm{JEV}^{12}$. Consideration should be given to active immunisation of young pigs against JEV.

4. Human Immunisation. Unfortunately antimosquito measures are never fully effective. The Dharan Cantonment is surrounded by ideal mosquito breeding terrain where amplifying animal hosts abound. The flight range of the prime vector Culex tritaeniorrhynchus of at least $1800 \mathrm{~m}^{36}$ implies that the Cantonment mosquito population can be constantly reinforced by potentially infected mosquitoes flying in from outside, so local antimosquito measures are unlikely to abolish the risk. This raises the question of active immunisation. Serological testing of 20 British Military personnel living on the Dharan Cantonment showed all to be fully susceptible to JEV. This contrasts with the locally employed Nepalese civilians $55 \%$ of whom had JEV antibody in their serum. The risk to British soldiers and their families is therefore great, not only in the context of susceptibility but in the light of a 10-20 fold increase in the encephalitis rate compared with local people ${ }^{13,31,32,33}$. A killed mouse brain (BIKEN) vaccine which employs the NakayamaNIH strain of JEV exists. In its present form over 82 million doses have been issued since $1966^{37}$. It appears to be extremely safe $\mathrm{e}^{37,38,30}$ and effective ${ }^{38,40}$ at least against Japanese JEV. Unfortunately there is no certainty that the wild Nepalese JEV is of that strain. Indeed evidence from Thailand ${ }^{37}$ and India $^{38,41}$ suggests that local strains of JEV exist and that although the vaccine may offer some protection, it appears to be less effective against local strains than the Japanese $\operatorname{strain}^{37,38}$. However until other vaccines become available it would seem sensible to offer Biken vaccine to British Military personnel and families living in or visit-क्ष ing Nepal.

The introduction of mass immunisation by induc-on ing serum antibodies might cloud the serological diagnosis of $\mathrm{JE}$ in vaccinees. Both immunisation and wild infection with JEV (apparent and in-O apparent) induce serum antibodies, but it has recentlyo been shown in Thailand that only wild infection $\frac{\text { s. }}{5}$ producing clinical encephalitis induces antibody市 formation in CSF. The antibody titres are tiny buto are quite diagnostic even at an early stage of the disease using an enzyme linked immunosorbant assay? technique ${ }^{42}$. This new technique therefore offers a $\overrightarrow{\vec{\omega}}$ rapid diagnosis of $\mathrm{JE}$ even in people previouslyo vaccinated.

The current research needs to be extended to evaluate the herd immunity of British Gurkha? soldiers serving in Nepal and to attempt virus isola- $-\tilde{C}$ tion either from patients or mosquitoes, not only toó confirm identification of JEV but to test the pe tective effect of neutralising antibody raised EIKEN vaccine against the wild virus.

\section{Acknowledgements}

I wish to thank Professor D H Simpson, Dr कृतo Leake, Dr E Gould and Lt Col D S Burke for their help with the antibody assays, Dr P Karki, Majoro General H S Moore, Brigadier M Brown, Cologe E E Vella and Dr N R H Burgess for their advice and encouragement, the physicians of the RANG previously in post in Dharan and finally $\mathrm{Mr} R \overrightarrow{\mathrm{aj}}-\overline{\mathrm{O}}$ kumar Rai who typed the manuscript.

\section{REFERENCES}

1 Rajagopalan, P K and Panicker, K N. A note on the 1976 epidemic of Japanese Encephalitis in? Burdwan District, West Bengal. Indian J Med Res 1978; 68: 393-398.

2 Soman, R S et al. A report on the mosquitoes collected during an epidemic of encephalitis in Burdwan District, West Bengal. Indian I Med Res 1976; 64: 808-813.

3 Japanese Encephalitis Surveillance. WHO Wkly. Epidem. Record 1982; 42: 327.

4 Japanese Encephalitis Surveillance. WHO Wkly. Epidem. Record 1982; 43: 331-332.

5 REUBEN, $R$. Studies on the mosquitoes of North Arcot District, Madras State. India I Med Ento $1971 ; 8: 363-366$.

6 BUESCHER, E L et al. Ecological Studies of Jap anese Encephalitis Virus in Japan: Mosquito Infection. Amer J Trop Med Hyg 1959; 8: 651-663. N

7 Wang, S P, Grayson, J $\dot{T}$ and Hu, S M K. Encephalitis on Taiwan: Virus Isolation from mos- 0 quitoes. Amer J Trop Med Hyg 1959; 11: 141-148. N 
8 HoKe, C H. Armed Forces Research Institute of Medical Sciences Bangkok. Personal communication.

9 CareY, D E et al.. Japanese Encephalitis Studies in Vellore, South India. Ind J Mid Res 1958; 56: 1340-1351.

10 Reuben, R. Studies on the mosquiioes of the North Arcot District, Madras State, India. J Med Ent 1971; 8: $314-318$

11 Okuno, $\mathrm{T}$ et al. Seasonal infection of Culex mosquitoes and swine with Japanese Encephalitis Virus. Bull. Wld. Hlth Org. 1973; 49: 347-352.

12 Hurblut, H S. The pig mosquito cycle of Japanes: Encephalitis virus in Taiwan. $J$ Med Ent 1964; 1: $301-307$.

13 GoRDon-SMith, C E. Studies on Arbovirus Epidemiology associated with established and developing rice culture. Trans. Roy Soc Trop Med Hyg 1970; 64: 481-482.

14 Gould, D J et al. Studies of Japanese Encephalitis Virus in the Chiangmai Valley, Thailand. Amer $J$ Epid 1974; 100: 49-56.

15 Gould, D J, Byrne, R J and Hayes, D E. Experimental infection of horses with Japanese Encephalitis Virus by Mosquito bite. Am J Trop Med Hyg 1964; 13: 742-746.

16 KAUL, H N et al. Serological evidence of arbovirus activity in birds and small mammals in Japanese Encephalitis affected areas of Bankura District, West Bengal. Ind J Med Res 1976; 64: 1735-1739.

17 Soman, $\mathbf{R} \mathbf{S}$ et al. Experimental Viraemia and Transmission of Japanese Encephalitis Virus by mosquitoes in ardeid birds. Ind J Med Res 1977; 66: 709-718.

18 Dhanda, $\mathrm{V}$ et al. Exparimental viraemia and transmission of Japanese Encephalitis Virus by mosquitoes in domestic ducks. Ind J Med Res 1977; 66: 881-888.

19 Buescher, E L et al. Immunologic Studies of Japanese Encephalitis Virus in Japan: Antibody responses following overt infection of man. J Immunol 1959; 83: 582-593.

20 SCHERER, W F et al. Immunological studies of Japanese Encephalitis Virus in Japan: Antibody responses following inapparent human infection. $J$ Immunol 1959; 83: 595-602.

21 Carey, D E, Myers, $R$ M and PaVRi, $K$ M. Japanese Encephalitis Studies in Vellore, South India: Antibody response of patients. Ind $J \mathrm{Med}$ Res 1968; 56: 1319-1329.

22 Grayson, J T, Wang, S P and Yen, C H. Encephalitis on Taiwan. Am J Trop Med Hyg 1959; 11: $126-130$.

23 Lincoln, A F and Sivirtson, S E. Acute Phase of Japanese Encephalitis. Journ Amer Med Assc 1952; 150; 268-273.

24 Sen Gupta, S N et al. Clinical Profile of the epidemic of Japanese Encephalitis in Bankura. Ind $J$ Med Res 1976; 64: 1393-1402.
25 MUKHERJEe, L et al. Serological studies in acute viral encephalitis. Ind Paeds 1977; 14: 25-28.

26 Biswas, S K et al. Epidemic of Japanese Encephalitis in Bankura (1973): Clinicopathological findings. Ind J Med Res 1976; 64: 801-80\%.

27 BuRKE, D S and NisalaK, A. Detection of Japanese Encephalitis Virus Immunoglobulin $\mathbf{M}$ antibodies in serum by antibody capture radioimmunoassay. $J$ Clin Microbiol 1982; 15: 353-361.

28 Burke, D S, Nisalak, A and Ussery, M A. Antibody Capture Immunoassay Detection of Japanese Encephalitis Virus IgM and Ig $G$ antibodies in CSF. J Clir Microbiol 1982; 16: 1034-1042.

29 Pennington N E and Phelps C A. Identification of the host range of Culex tritaeniorrhynchus mosquitoes on Okinawa, Ryuky Islands. $J$ Med Ent 1968; 5: 483-487.

30 Mitchell, C J, Chen, P $S$ and Boreham, P F L. Host feeding patterns and behaviour of 4 Culex species in an endemic area of Japanes Encephalitis. Bull Wld Hlth Org 1973; 49: 293-299.

31 Southam, C M. Serological studies of encephalitis in Man: Inapparent infections by Japanese encephalitis virus. J Inf Diseases 1956; 99: 163-169.

32 Grossman, $R$ A, Edelman, $R$ and Gould, D J Study of Japanese Encephalitis Virus in Chiangman Valley, Thailand: Summary and Conclusion. Am Epidemiol 1974; 100: 69-76.

33 Benenson, $M W$ et al. The Virulence to man of Japanese Encephalitis Virus in Thailand. $A m$ Pे Trop Med Hyg 1975; 24: 974-980.

34 Hu, S M K and Grayson, J T. Encephalitis on Taiwan. Mosquito collection and Bionomic studies Am J Trop Med Hyg 1959; 11: 131-138.

35 Mitchell, C P and Chen, P S. Ecological studies on the mosquito vectors of Japanes? Encephalitis? Bull Wld Hlth Org 1973; 49: 287-292.

35 BaIley, G L and Gould, D J. Flight and dispersa, of Japanese Encephalitis Vectors in Northern Thailand. Mosquito News 1975; 35: 172-178.

37 BurKe, D S. Armed Forces Research Institute of Medical Sciences Bangkok 1983. Personal communication.

38 Das, B C et al. Comparative Study of Protection by Japanese Encephalitis Vaccine against Japanese and an Indian strain of Japanese Encephalitis Vaccine. Ind J Path Microbiol 1976; 19(4): 239-243.

39 In: Immunisation for Japanese Encephalitis. Publisher Igaku Shoin Ltd, Tokyo 1971; 275-277.

40 In: Immunisation for Japanese Encephalitis. Publisher Igaku Shoin Ltd, Tokyo 1971; 258-265.

41 Carey, D E, Reuben, R and Myers, R M. Japanese Encephalitis Studies in Vellore South India: Virus isolation from Mosquitoes. Ind J Med Res 1958; 56: 1309-1318.

42 BURKe, D S. Diagnosis of Flavivirus Encephalitis by Detection of IgM antibodies in CSF. Research Report: Walter Reed Army Institute of Research 1982; 3: 2-3. 